УДК $551.336 ” 626 “(571.56+571.65)$

\title{
РЕКОНСТРУКЦИЯ МАСШТАБОВ И МОРФОЛОГИЧЕСКИХ ОСОБЕННОСТЕЙ ПЛЕЙСТОЦЕНОВЫХ ОЛЕДЕНЕНИЙ НА СЕВЕРО-ВОСТОКЕ РОССИИ
}

\author{
Глуикова О. Ю., Смирнов В. Н. \\ ФГБУН Северо-Восточный комплексный научно-исследовательский институт \\ им. Н. А. Шило ДВО РАН, г. Магадан \\ E-mail: glushkovaoyu@yandex.ru
}

\begin{abstract}
На основе имеющихся данных установлено, что самые ранние оледенения в западной Берингии возникали в позднем эоплейстоцене и в конце раннего неоплейстоцена. Они имели локальное распространение в наиболее поднятых частях хр. Черского. Их следы представлены в виде морен, заключенных в осадках межгорных впадин. Ледниковые формы этого возраста в рельефе гор и равнин региона не установлены. Средне-неоплейстоценовое оледенение было самым крупным и по площади распространения, и по длине отдельных ледников. Оно было горно-долинным и сетчатым, в отдельных районах - горно-покровным. По времени это оледенение совпадает с этапом активизации восходящих неотектонических движений в среднем неоплейстоцене. Следы двух поздне-неоплейстоценовых оледенений хорошо выражены в рельефе в виде экзарационных, моренных и водно-ледниковых комплексов. Первое поздне-неоплейстоценовое оледенение значительно уступало по всем параметрам средненеоплейстоценовому, но оно также было обширным и оставило в предгорьях крупные амфитеатры конечных морен. Гляциальные комплексы последнего поздне-неоплейстоценового оледенения распространены на площадях, в 2-3 раза меньших предшествовавшего, и, как правило, находятся внутри его контуров.
\end{abstract}

Ключевые слова: неоплейстоцен, оледенения, ледники, конечно-моренные формы, гляциальные районы, Северо-Восток России.

DOI: 10.34078/1814-0998-2021-2-50-67

\section{ВВЕДЕНИЕ}

Вопросы палеогеографической реконструкции и корреляции плейстоценовых оледенений на Северо-Востоке России рассматривались в разные годы во многих работах (Колосов, 1947; Васьковский, 1959; Баранова, 1960; Шило, 1961; Воскресенский и др., 1984; Глушкова, 1984, 1986; и др.). В отдельных ледниковых районах было проведено детальное изучение морфологии и палеогеографии разновозрастных ледниковых комплексов (Веснин и др., 1962; Глушкова, Прохорова, 1987; и др.). По данным геологического картирования и тематических работ были выделены ледниковые горизонты средне-неоплейстоценового и поздне-неоплейстоценового возраста. По представлениям некоторых исследователей (Шило, 1961; и др.), в Верхне-Колымском регионе оледе-

(C) Глушкова О. Ю., Смирнов В. Н., 2021 нение среднего неоплейстоцена было максимальным, хотя и развивалось, как тогда считалось, в условиях менее поднятого и менее расчлененного рельефа, чем современный (Шило, 1961).

В Охото-Кухтуйской впадине и ее горном обрамлении были установлены горизонты основной морены, возраст которых, по данным термолюминесцентного анализа, был определен как верхняя часть среднего неоплейстоцена. Предполагалось, что оледенение этого времени было горно-покровным (Ананьев и др., 1984).

На Чукотском полуострове плейстоценовые оледенения выделялись главным образом на основании анализа ледниково-морских отложений. О. М. Петровым (1966) были установлены четыре ледниковых горизонта: нижне- и среднеплейстоценовые и два верхнеплейстоценовых. В результате последующих исследований в этом регионе установлены следы трех неоплейстоценовых оледенений горно-долинного и карового 
типов (Иванов, 1986). По мнению В. Ф. Иванова, проследить границы распространения многих ледников на суше не представляется возможным, так как они выходили в пределы осушенного шельфа, о чем свидетельствуют обнаруженные затопленные конечно-моренные валы и гряды.

В Корякском нагорье, по данным Ю. П. Дегтяренко (1984), были установлены следы только двух позднеплейстоценовых и голоценового оледенений.

Вместе с тем морфологические особенности и масштабы плейстоценовых оледенений на большей части Северо-Востока России до настоящего времени остаются слабо изученными. Это объясняется тем, что выполненные ранее реконструкции плейстоценовых ледниковых событий базировались в основном на немногочисленных и неравнозначных по качеству материалах, позволявших лишь очень схематично представить районы распространения древних ледников. Ограничены были также и возможности корреляции ледниковых отложений и форм рельефа на обширных территориях с разными орографическими и климатическими условиями. В последние годы в связи с появлением новых методов датирования, а также в результате дешифрирования разномасштабных спутниковых снимков появилась возможность проведения сравнительного морфологического и палеогеографического анализа древних ледниковых районов на всей территории СевероВостока России. Поэтому удалось более обоснованно оконтурить ареалы плейстоценовых оледенений и выделить основные ледниковые центры, а также определить размеры, пути движения и возраст отдельных ледников и на этой основе существенно уточнить возраст, масштабы и типы неоплейстоценовых оледенений.

Особенно радикально изменились взгляды на возраст и параметры ледниковых событий в Верхоянском хребте, где по данным анализа коррелятных комплексов методом оптикостимулированной люминесценции (ОСЛ) установлено 5 ледниковых экспансий в период от 140 до 60 тыс. л. н. (Stauch et al., 2007). Существенно поменялись и представления о возрасте и масштабах оледенений в хр. Черского, в некоторых горных сооружениях Тихоокеанско-Арктического водораздела, в Корякском нагорье и в других регионах Северо-Востока России (Глушкова, Прохорова, 1989; Шило и др., 2001; Glushkova, 2001, 2011; Novaczyk et al., 2002; Глушкова, 2006, 2015; Stauch, Gualtieri, 2008; и др.).

\section{МЕТОДЫ ИССЛЕДОВАНИЙ}

Для обобщения региональных материалов по определению распространения, характера и стадийности развития неоплейстоценовых оледенений на Северо-Востоке России в качестве основ- ного метода нами использован сравнительный геоморфологический анализ ледниковых форм. Авторами выполнено дешифрирование ледниковой морфоскульптуры на аэро- и космических снимках на всю территорию СевероВостока России. В ключевых районах горной системы Черского (хр. Улахан-Чистай, Анначаг), Северного Приохотья (хр. Билибина, Ичигемский, горы Хэл-Урэкчэн и др.), а также п-ова Тайгонос и Корякско-Анадырской области проведено изучение форм ледникового рельефа и коррелятных отложений. При обосновании возраста и хронологической корреляции ледниковых комплексов использованы собственные и заимствованные из опубликованных источников определения возраста коррелятных образований по данным их палинологического и палеокарпологического изучения, а также методами абсолютного датирования: термолюминесцентным и ОСЛ, а также методами радиометрического датирования: радиоуглеродного по ${ }^{14} \mathrm{C}$ и космогенного по ${ }^{36} \mathrm{Cl}$ анализов. В работе наряду с полевыми наблюдениями использованы аэрофотоснимки высокого разрешения, а также материалы спутниковой съемки, представленные в Интернет-ресурсе Google Earth. Спутниковые снимки сопровождаются разнообразными сервисными функциями, которые позволяют в рамках одной задачи быстро переходить от обзорных изображений к детальным с высоким разрешением, от плановых изображений - к перспективным и т. п. Кроме того, на этих снимках возможно определение координат и расстояний, измерение линейных и площадных параметров форм рельефа, варьирование цветовыми эффектами и др. Вследствие этого применение современной спутниковой информации позволило существенно уточнить полученные ранее данные о морфографии и морфометрии ледниковых комплексов и их пространственных соотношениях. Палеогляциологические исследования форм ледникового рельефа сопровождались полевым изучением коррелятных отложений. Картографирование выделенных разновозрастных комплексов осуществлялось на основании сравнительного анализа степени сохранности гляциальных форм рельефа разных ледниковых эпох и их расположения относительно горных узлов (центров оледенения), которые являлись областями питания ледников.

Общее стратиграфическое положение ледниковых комплексов определялось в соответствии с российской Стратиграфической шкалой четвертичной системы (Янина, 2014). Согласно этому они относятся к верхнему эоплейстоцену, к нижнему, среднему и верхнему неоплейстоцену. 


\section{ДАННЫЕ О РЕЛЬЕФЕ И КЛИМАТЕ РЕГИОНА}

Обширная территория Северо-Востока России обладает большим орографическим разнообразием и охватывает несколько климатических зон. В связи с этим она дает хорошие возможности для изучения особенностей развития неоплейстоценовых оледенений в разных орографических и климатических условиях и для решения проблем региональной корреляции ледниковых событий. По абсолютным высотам и относительным превышениям хребтов, а также по гипсометрическому положению реликтов плиоценовой поверхности выравнивания и другим геоморфологическим признакам в изучаемом регионе выделяются 4 типа рельефа: альпинотипное среднегорье (абсолютные высоты более 1500 м) с большим количеством каров, троговых долин и других форм гляциального рельефа; резко расчлененное низкогорье (от 700 до 1500 м); пологосклонное низкогорье (до 700 м); холмистые равнины прибрежных низменностей (до 200 м) и межгорных впадин (более 200 м).

Главными горными сооружениями рассматриваемой территории являются: Верхоянский хребет, горная система Черского, хребты и нагорья Охотско-Чукотской горной области, образующие Тихоокеанско-Арктический водораздел, а также Корякское нагорье. Основу рельефа составляют низкогорья высотой до 1500 м, над которыми возвышаются среднегорные хребты и горные узлы высотой до 2000-3000 м. Равнинный рельеф распространен на прибрежных низменностях (ЯноИндигирская, Колымская, Нижне-Анадырская и др.) и в крупных межгорных впадинах вблизи побережий Охотского моря.

Исследованный регион относится в основном к Субарктическому поясу и в меньшей степени к Арктическому - побережье и острова Северного Ледовитого океана. Он охватывает несколько климатических зон: арктической пустыни и арктической тундры; тундры и лесотундры, а также зону климата хвойных лесов. Для обширных районов в центральной части Северо-Востока России характерен резко континентальный климат с очень морозной зимой и относительно высокой сухостью. Умеренно континентальный и морской климат имеет место на востоке Чукотки, в Корякском нагорье и в пределах 50-100-километровой зоны вдоль побережья Охотского моря. Этим районам свойственны холодное лето и достаточно большое увлажнение. Вся территория региона в целом обладает большой и очень большой суровостью погодных условий (Клюкин, 1970).

В горах Северо-Востока России имеются горно-долинные ледники. Наиболее крупные из них сосредоточены в хр. Сунтар-Хаята, Черского и в Корякском нагорье. Небольшие ледники име- ют место также и в других горных сооружениях Северного Приохотья и Чукотки. Но в целом климатические условия, несмотря на продолжительные сезоны с очень низкими температурами, не благоприятствуют развитию оледенений из-за недостаточного количества осадков в зимний период, на что уже давно указывали многие исследователи этой проблемы.

\section{ОСНОВНЫЕ ЭЛЕМЕНТЫ ГЛЯЦИАЛЬНОЙ МОРФОСКУЛЬПТУРЫ}

В горных районах Северо-Востока России основные экзарационные формы рельефа - кары и троги, особенно многочисленны в приводораздельных частях хребтов, что придает им альпинотипный облик.

Кары являются наиболее выразительным элементом современного ландшафта гор СевероВостока России (Глушкова, 1984, 1986). Основополагающее значение каров заключается в том, что ими маркируются ледниковые центры - области питания ледников. Для каровой морфоскульптуры в горах Северо-Востока России характерны следующие орографические особенности: подавляющее большинство каров ориентировано в северных румбах; в каждом районе днища каров приурочены к определенному гипсометрическому уровню, который соответствует высоте снеговой границы в ледниковую эпоху. Он колеблется в широких пределах: от 600 м в прибрежных низкогорных районах до 1300 м - в удаленных от побережий горных сооружениях (Смирнов, Глушкова, 2012; Глушкова, Смирнов, 2020).

Троги. Не менее важное значение для палеогеографических реконструкций плейстоценовых оледенений имеет изучение таких крупных экзарационных форм ледникового рельефа, как троговые долины. В верховьях рек в ледниковых районах Северо-Востока России имеются хорошо сохранившиеся троговые долины, которым свойственна типичная корытообразная форма, и в истоках они завершаются ледниковыми карами. У них плоское днище, покрытое глыбовым материалом основной морены, образующей холмы различной высоты и небольшие изометричные котловины, а также подпруженные моренами ледниковые озера. Часто вдоль бортов троговой долины расположены плечи трогов, протяженные валы боковой морены и маргинальные каналы (Глушкова, Прохорова, 1987). Эти формы рельефа являются важными критериями морфологии и оценки мощности ледников а также характера взаимодействия ледника с ложем долины и горными склонами. Изучение пространственного расположения троговых долин оказывает также решающее влияние на оценку площадей, морфологии и типа оледенения. 
Конечно-моренные комплексы. Терминальные формы ледниковой аккумуляции разного возраста сохранились в основном во впадинах, на предгорных равнинах, в сквозных долинах. Они представлены конечно-моренными валами и грядами, водно-ледниковыми террасами и полями зандров. Особое значение для определения ареалов, характера, стадийности развития неоплейстоценовых оледенений имеют конечноморенные валы. В ходе иследований установлены количество, размеры, особенности морфологии, степень сохранности конечно-моренных форм в ледниковых долинах и на этой основе определены границы распространения ледников и стадии их развития. Выделены серии напорнонасыпных конечных морен, которыми отмечены осцилляции края ледника во время его максимального продвижения. Часто наблюдаются от 2 до 7 сближенных валов, образующих амфитеатры, по которым может быть сделана оценка продолжительности перехода ледника от равновесной стадии к стадии необратимой деградации (Глушкова, 2015).

\section{ПАЛЕОГЛЯЦИОЛОГИЧЕСКОЕ РАЙОНИРОВАНИЕ}

Разнообразные формы ледникового рельефа широко распространены в горных областях рассматриваемого региона. Большей частью они приурочены к верхним, альпинотипным уровням гор, но вблизи морских побережий встречаются и в низкогорном рельефе. По физикогеографическому положению выделяются внутриконтинентальные и прибрежные ледниковые районы. В первых они приурочены к верхнему гипсометрическому уровню в альпинотипном среднегорье высотой 1500-3000 м. В прибрежных районах гипсометрический уровень распространения ледниковых форм рельефа снижается, они встречаются в низкогорьях высотой 8001500 м. Необходимо отметить, что при формировании обширных ареалов ледников конечноморенные комплексы отмечаются в равнинном рельефе межгорных и приморских впадин, на большом удалении от областей питания, расположенных в верхнем ярусе горных сооружений.

Изучение древних ледниковых форм, их возраста, распространенности, положения в рельефе и взаимоотношений, морфологии, степени сохранности позволило реконструировать палеогеогляциологические обстановки ледниковых эпох среднего и позднего неоплейстоцена. По данным геоморфологических и климатостратиграфических исследований, по результатам дешифрирования гляциальной морфоскульптуры на спутниковых материалах и аэротофотоснимках, а также по данным фитостратиграфического и изотопного датирования коррелятных осадков в рельефе Северо-Востока России выделены гляциальные комплексы четырех возрастных генераций: средне-неоплейстоценовые, поздне-неоплейстоценовые: зырянские, сартанские, а также голоценовые (Глушкова, 1986; Glushkova, 2011; Смирнов, Глушкова, 2012). Следы более древних оледенений, как будет показано далее, в рельефе никак не проявлены, они установлены только в разрезах эоплейстоцен-неоплейстоценовых и нижне-неоплейстоценовых отложений межгорных впадин.

Основными гляциальными элементами ландшафтов в ледниковых районах Северо-Востока России являются экзарационные формы (кары, троги) и аккумулятивные - холмисто-западинный рельеф основной морены, конечно-моренные валы и гряды, флювиогляциальные равнины. Из них самыми распространенными и важными для палеогляциологических исследований являются кары и конечные морены.

Указанные выше элементы гляциальной морфоскульптуры сосредоточены в нескольких обширных ареалах, которые приурочены к основным горным сооружениям региона Наиболее крупные из них находятся в самых высоких хребтах: Черского и Сунтар-Хаята и в Корякском нагорье, имеющих абсолютную высоту до 3000 м, представляют собой одноименные гляциальные районы (рис. 1). Для них характерен типичный альпийский рельеф с широким развитием каровой и троговой морфоскульптуры поздненеоплейстоценового возраста и с крупными современными ледниками. Горные сооружения Охотско-Чукотской области, образующие Главный (Тихоокеанско-Арктический) водораздел, простираются на северо-восток почти на 2400 км от впадающей в Охотское море р. Иня до Берингова пролива. В этой горной области выделяются следующие наиболее крупные орографические элементы: Колымское нагорье, Анадырское плоскогорье и Чукотское нагорье, которые включают в себя большое количество локальных хребтов. В Охотско-Чукотской области выделяются три гляциальных района. Колымо-Охотский район простирается в субширотном и северо-восточном направлении на 1200 км от р. Иня на западе до p. Пенжина - на востоке. Он охватывает Колымское нагорье, хр. Омсукчанский, Ичигемский и др., а также горные массивы п-овов Кони, Пьягина, Тайгонос. Далее к северо-востоку находится Анюйско-Олойский район, охватывающий хр. Уш-Урэкчен, Олойский, Анюйский и др. На восточной Чукотке, занимающей территорию, расположенную между Чукотским морем и Анадырским заливом Берингова моря, выделяется Чукотский ледниковый район.

В эпохи оледенений палеогеография СевероВостока России существенно отличалась от современной ландшафтной обстановки. В ледни- 


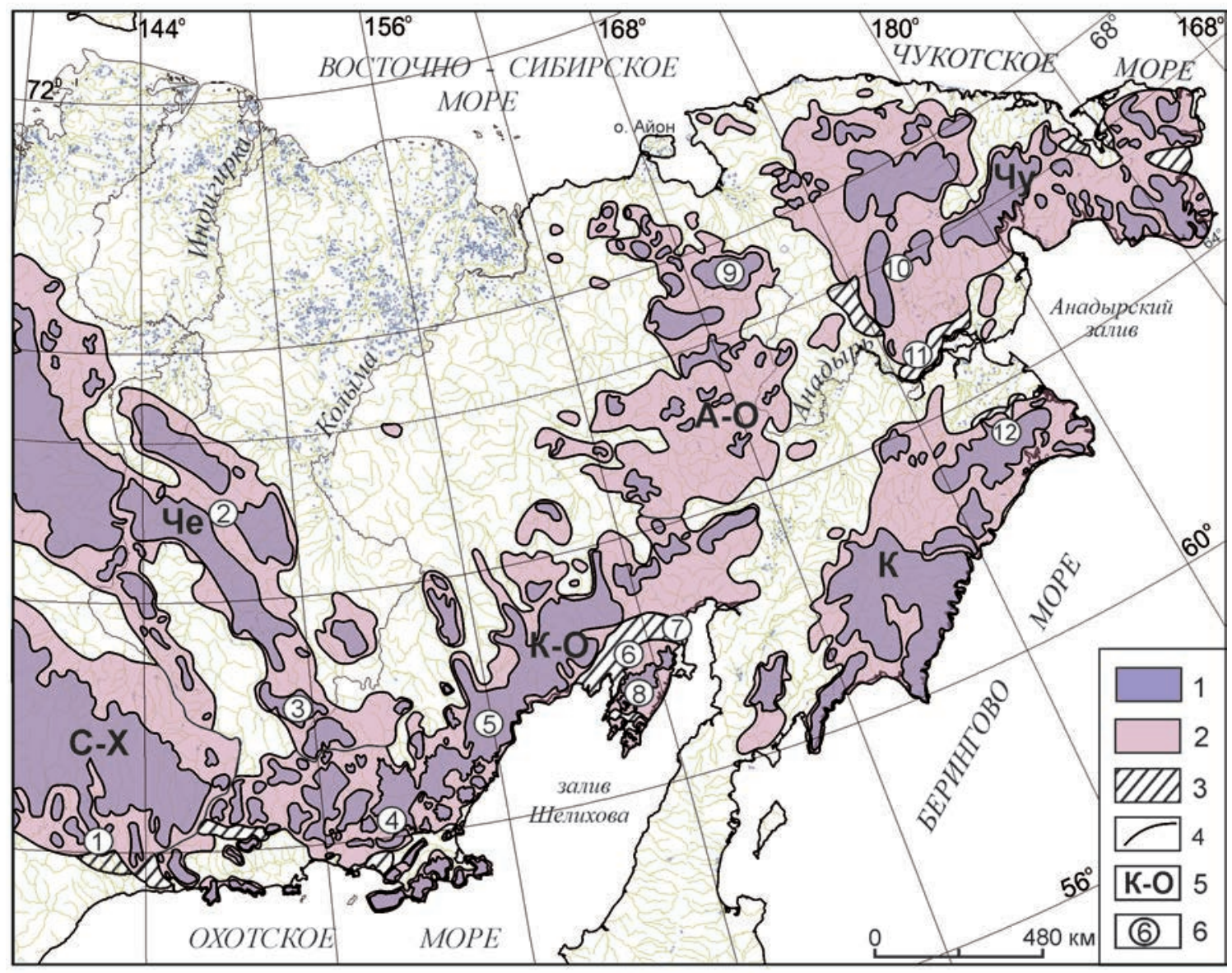

Puc. 1. Районы распространения и объекты изучения гляциальной морфоскульптуры на территории СевероВостока России. 1-3 - комплексы основной и конечной морен: 1 - средне-неоплейстоценовые; 2, 3 - верхненеоплейстоценовые: 2 - зырянские, 3 - сартанские; 4 - границы, 5 - названия гляциальных районов: $\mathbf{C - X}$ Сунтар-Хаята; Че - Черский; К-О - Колымо-Охотский; А-О - Анюйско-Олойский; Чу - Чукотский; К - Корякский. Пункты нахождения локальных гляциальных объектов (цифры в кружках): 1 - низовья рр. Урак, Охота; 2 - хр. Улахан-Чистай; 3 - хр. Бол. Анначаг; 4 - гряда Билибина; 5 - хр. Хэл-Урэкчэн; 6 - низовья р. Гижига; 7 - низовья р. Парень; 8 - хр. Тайнынотский; 9 - Илирнейский кряж; 10 - хр. Пекульней; 11 - низовья рр. Танюрер и Канчалан; 12 - оз. Майниц

Fig. 1. Distribution areas and objects of studying glacial morphosculpture in the North-East of Russia. 1-3 - complexes of the bottom and terminal moraines: 1 - Middle Neopleistocene; 2, 3 - Late Neopleistocene: 2 - Zyryan, 3 - Sartan; 4 - borders, 5 - names of glacial regions: C-X - Suntar-Khayata; Ye - Chersky; K-O - Kolyma-Okhotsk; A-O - Anyuisk-Oloy; Yy - Chukotka; K - Koryak. Glacial object locations: 1 - lower Urak R., Okhota R.; 2 - Ulakhan-Chistay Range; 3 - Bolshoy Annachag Range; 4 - Bilibin Range; 5 - Khal-Urekchen Range; 6 - lower Gizhiga R.; 7 - lower Paren R.; 8 - Tainynot Range; 9 - Ilirney Range; 10 - Pekulney Range; 11 - lower Tanyurer R. and Kanchalan R.; 12 - Lake Maynits

ковые эпохи происходило снижение уровня Мирового океана, осушение обширных пространств шельфа и отодвигание береговой линии на десятки и сотни километров. С этим связано увеличение площади континента и появление Берингийского моста суши, который разделял бассейны Тихого и Северного Ледовитого океанов.

\section{ХАРАКТЕРИСТИКА ЛЕДНИКОВЫХ КОМПЛЕКСОВ}

На территории Северо-Востока России достаточно полно изучены ледниковые комплексы позднего неоплейстоцена и голоцена. Оледенения этого возраста оставили после себя разно- образные и многочисленные следы в виде экзарационной и аккумулятивной морфоскульптуры, коррелятных отложений разного генезиса. Они отлично дешифрируются на аэрофотоснимках, поэтому их картографирование, морфологическое и морфометрическое изучение началось еще в ходе рекогносцировочных геологических съемок и особенно при проведении Государственного геологического картирования масштаба 1: 200 000. Полученные большие объемы фактических данных были положены в основу многочисленных научных работ, результаты которых опубликованы в различных изданиях. Представления о более древних оледенениях разрабатывались на другой, более ограни- 
ченной стратиграфической и палеогеографической базе в связи с тем, что их следы в рельефе и коррелятных отложениях запечатлены несравненно хуже, чем у поздне-неоплейстоценовых, они фрагментарны, степень их сохранности и представительности сильно варьирует. На Северо-Востоке России свидетельства самых древних ледников - позднеэоплейстоценовых и ранне-неоплейстоценовых установлены по данным геолого-съемочных и геологоразведочных работ только на локальных участках хр. Черского в составе осадочных толщ четвертичного возраста, которые заполняют межгорные впадины.

Верхне-эоплейстоценовые $\left(Q_{\mathrm{EII}}\right)$ слои ледниковых и водно-ледниковых отложений залегают на позднемезозойских породах верхоянского комплекса и на размытой поверхности осадочных слоев неогенового и неоген-эоплейстоценового возраста. Мощность толщи ледникового комплекса достигает 30 м. Предполагается, что это следы самого древнего в регионе четвертичного оледенения. Поздне-эоплейстоценовый возраст отложений принимается в соответствии с решениями Межведомственного стратиграфического совещания по четвертичной системе СевероВостока СССР (1982 г.) и Легендой ВерхояноКолымской серии листов Государственной геологической карты масштаба 1:1 000000 (третье поколение).

Нижне-неоплейстоценовые $\left(Q_{I}{ }^{2}\right)$ ледниковые и водно-ледниковые отложения установлены в тех же районах. Они залегают на цоколях террас высотой до 40 м и во впадинах в составе осадочных толщ четвертичного возраста, имеют мощность 8-20 м. По возрасту они относятся к верхней части раннего неоплейстоцена и соответствуют левоберелехскому горизонту. Есть указания на то, что нижне-неоплейстоценовые ледниковые отложения присутствуют в СевероЗападном Приохотье (басс. р. Урак). Они встречаются только в разрезах и не выражены в современном рельефе (Ананьев и др., 1984).

\section{СРЕДНЕ- И ВЕРХНЕ-НЕОПЛЕЙСТОЦЕНОВЫЕ ЛЕДНИКОВЫЕ КОМПЛЕКСЫ}

В отличие от предшествовавших оледенений, ледниковые комплексы среднего и верхнего неоплейстоцена сохранились более широко и, что самое важное, представлены в виде не только моренных слоев в разрезах четвертичных отложений впадин и крупных речных долин, но и форм ледникового рельефа.

Средне-неоплейстоценовые $\left(\mathrm{Q}_{\mathrm{II}}{ }^{2}\right)$ ледниковые и водно-ледниковые отложения и формы рельефа выделялись в ходе геологического картирования масштаба 1: 200000 и тематических исследований на обширных площадях в пределах гляциальных районов Сунтар-Хаята, Колымо-
Охотского и Чукотского. Аккумулятивные формы ледникового рельефа среднего неоплейстоцена распространены главным образом на поверхности Охото-Кухтуйской, Гижигинской, Нижне-Анадырской и других низменностей, а также на равнинах межгорных впадин и в предгорьях. Они часто расположены в долинах крупных рек: Охота, Гижига, Парень, Белая, Анадырь и др. Эти ледниковые комплексы находятся на большом удалении от областей питания, имеют большие размеры и сильную преобразованность эрозионно-денудационными процессами. Они часто представлены полями основной морены в виде беспорядочно расположенных моренных холмов и гряд, разделенных западинами и озерами. В некоторых районах достаточно полно сохранились фрагменты конечно-моренных дуг, которые позволяют оценить масштабы оледенения. Спорово-пыльцевые комплексы из ледниковых и флювиогляциальных отложений характеризуют холодолюбивую растительность верхней части среднего неоплейстоцена (Шило, 1961; Воскресенский и др., 1984). По данным указанных авторов, оледенение среднего неоплейстоцена было максимальным. В некоторых районах получены изотопные датировки в пределах верхней части среднего неоплейстоцена, которые являются опорными для стратиграфических и геоморфологических корреляций.

Охото-Кухтуйская равнина и ее горное обрамление. По данным Г. С. Ананьева и др. (1984), средне-неоплейстоценовые конечно-моренные комплексы установлены в южной части ледникового района Сунтар-Хаята, в пределах ОхотоКухтуйской равнины и ее горного обрамления. Изучены разрезы конечно-моренных ледниковых отложений в долинах рр. Урак, Охота и их притоков - рр. Юровка и Селемджа (см. рис. 1). Они расположены на большом удалении от областей питания ледников (до 250 км), имеют большие размеры и явно выраженный «дряхлый облик», обусловленный длительным воздействием эрозионных, криогенных и денудационных процессов. Возраст средне-неоплейстоценовых ледниковых слоев определен, по данным указанных выше авторов, в центральной части Охото-Кухтуйской равнины («Номанкурский разрез») и вблизи ее северной границы («Селемджинский разрез»). Здесь р. Охота на протяжении около 300 м вскрывает 3 гляциальных горизонта: морену, а также флювиогляциальные и лимногляциальные отложения общей мощностью около 30 м. По данным термолюминесцентного анализа коррелятных отложений, подстилающих и перекрывающих морену, установлено, что они формировались в интервале от $135 \pm 34$ до $148 \pm 40$ тыс. лет, что соответствует тазовскому оледенению (МИС 6) в Западной Сибири (Ананьев и др., 1984). 
Гижигинская равнина и п-ов Тайгонос. В пределах Колымо-Охотского гляциального района на Гижигинской равнине установлены конечно-моренные комплексы, образованные ледниками, стекавшими с южных склонов Главного водораздела на расстояние 140-170 км (рис. 2). Они представлены сильно разрушенными грядами и валами длиною до 30 км. По материалам геолого-съемочных работ среди реликтов древних моренных образований установлены коррелятные отложения, имеющие по палинологическим данным средне-неоплейстоценовый (нерасчлененный) возраст. На рис. 2,А показаны соотношения ареалов развития средне- и поздне-неоплейстоценовых оледенений на п-ове Тайгонос (в Тайнынотском хребте) и на Гижигинской равнине. Видно, что площади распространения основной морены, размеры конечноморенных форм и их удаление от областей питания средне-неоплейстоценового оледенения намного превосходят аналогичные характеристики поздне-неоплейстоценовых оледенений. Такие же соотношения характерны для всех ледниковых районов Северо-Востока России (Глушкова, Смирнов, 2020). По степени сохранности, размерам и гипсометрическому положению в рельефе аккумулятивные моренные комплексы заметно различаются. Самый дряхлый сильно разрушенный и преобразованный аллювиальными и криогенными процессами конечно-моренный комплекс среднего неоплейстоцена осложняет поверхность Гижигинской равнины в приустьевой части р. Гижига. Серия конечно-моренных гряд хорошо выделяется на космических снимках. Внешняя гряда расположена в 170 км от области питания, ее фронтальная часть достигает берега моря. Она состоит из отдельных фрагментов, разделенных современными водотоками. Длина гряды составляет 32 км, ее ширина на некоторых участках превышает 2.5-3 км. Две внутренние гряды сохранились хуже. Ясно выраженные валы наблюдаются только на левобережье p. Гижига. Максимальное расстояние между двумя внешними валами 4.0 км. В периферической части валы сливаются в единую гряду. Выше по течению р. Гижига, на расстоянии 30-32 км наблюдается еще одна сильно разрушенная гряда длиною около 30 км. Ширина этой гряды составляет около 5 км. Для нее характерно большое количество озер, заполняющих понижения, и слабо врезанных водотоков, соединяющих озера.

Крупные конечно-моренные комплексы среднего неоплейстоцена дешифрируются в юговосточном обрамлении Гижигинской равнины (рис. 2,Б). Здесь фрагменты размытых, в значительной степени преобразованных конечноморенных валов обнаружены на междуречье Ко- лымака и Пареня. Озеро Парень с юга и востока обрамлено морфологически хорошо выраженной моренной грядой, разделенной на несколько фрагментов.

Общая длина этой гряды около 23 км, ширина 1.5-2.5 км, а высота около 40 м. Вал рассечен долиной р. Парень, небольшими ручьями и заболоченными седловинами на ряд фрагментов и имеет относительную высоту 50-60 м.

Удаление отмеченных ледниковых форм от области питания, которая располагалась в Ичигемском хребте, достигает 160 км. В среднем неоплейстоцене ледники покрывали также многие достаточно высокие горные хребты и массивы в северо-восточной части Колымского нагорья.

Нижне-Анадырская низменность и ее горное обрамление. В Чукотском гляциальном районе конечно-моренные комплексы изучены в басс. pр. Танюрер, Канчалан, Юрумкувеем, Осиновая (левые притоки р. Анадырь) и в других местах (рис. 2,В). По данным геолого-съемочных работ среди реликтов древних моренных образований установлены коррелятные отложения, имеющие средне-неоплейстоценовый (нерасчлененный) возраст. Как и в других районах, они отличаются от более молодых терминальных комплексов тем, что расположены на значительно большем удалении от областей питания, имеют более крупные размеры и сильную преобразованность эрозионно-денудационными и криогенными процессами. $\mathrm{O}$ масштабах средне-неоплейстоценового оледенения в этом районе свидетельствует широкое распространение основной морены с характерным холмистозападинным рельефом и многочисленными озерами на поверхности Нижне-Анадырской низменности (Новейшие..., 1980; Ложкин и др., 2005). Ледниковые образования разной степени сохранности прослежены от областей питания ледников, которые находились на южных макросклонах горных массивов Главного водораздела и в осевой части хр. Пекульней, по долинам pp. Юрумкувеем и Бол. Осиновая на расстоянии до 220 км, по р. Танюрер - до 300 км, по р. Канчалан - до 180 км.

Крупные конечно-моренные амфитеатры, которые относятся к средне-неоплейстоценовому оледенению (см. рис. 1), установлены в приустьевой части Танюрера на левобережье p. Анадырь, где они «подпирают» р. Анадырь, вследствие чего на его правобережье образовалось крупное подпрудно-ледниковое оз. Красное. Высота отдельных гряд достигает 4080 м, ширина колеблется от 1.5 до 3 км, а протяженность превышает 30 км (Баранова, 1960; Веснин и др., 1962; Глушкова, Прохорова, 1989). Палеогеографические реконструкции показали, что Танюрерский ледник был одним из 

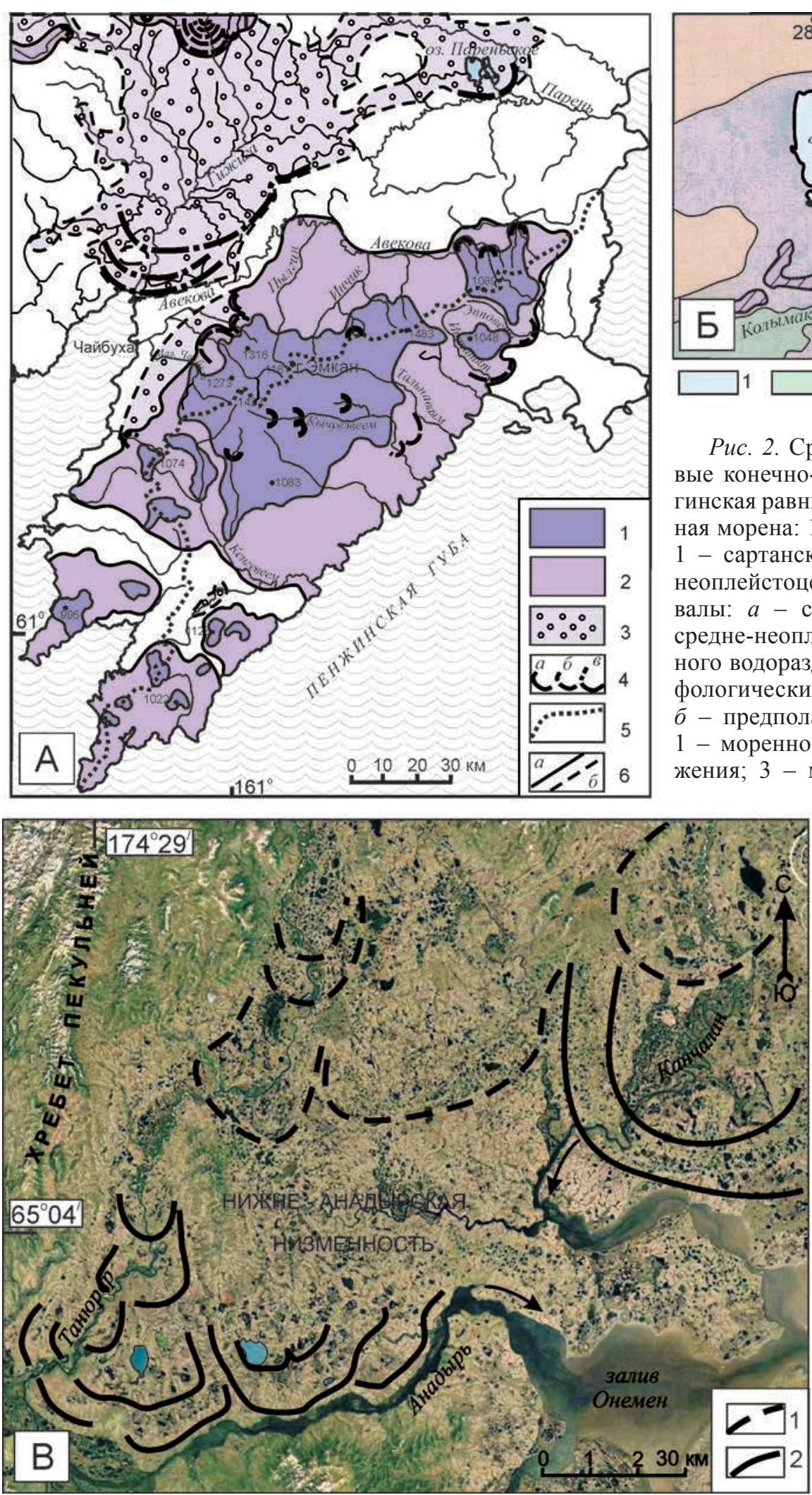

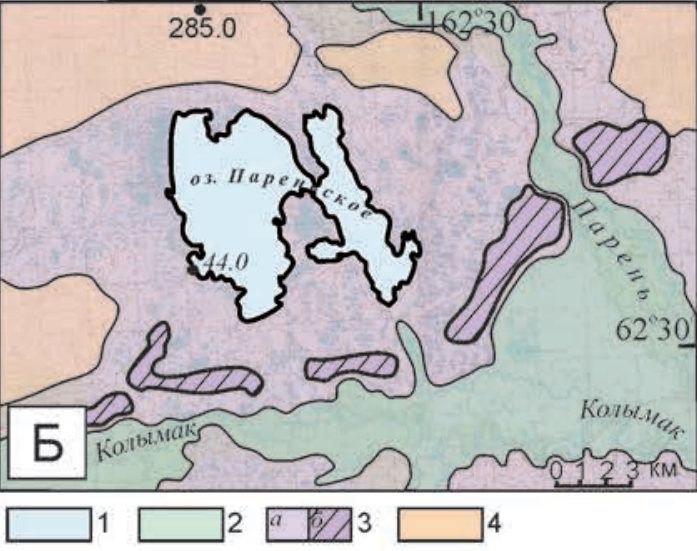

Puc. 2. Средне- и верхне-неоплейстоценовые конечно-моренные комплексы. А. Гижигинская равнина и п-ов Тайгонос: $1-3$ - основная морена: 1, 2 - верхне-неоплейстоценовая: 1 - сартанская, 2 - зырянская; 3 - средненеоплейстоценовая; 4 - конечно-моренные валы: $a$ - сартанские, б - зырянские, в средне-неоплейстоценовые; 5 - линия главного водораздела п-ова Тайгонос; 6 - геоморфологические границы: $a$ - установленные, $\sigma$ - предполагаемые. Б. Низовья р. Парень: 1 - моренное озеро; 2 - аллювальные отложения; 3 - моренный комплекс: $a$ - основная морена, б - фрагменты конечно-моренного вала; 4 участки низкогорья, не покрывавшиеся льдом. В. НижнеАнадырская равнина: конечноморенные валы верхне-неоплейстоценовые (1), средненеоплейстоценовые (2)

Fig. 2. Middle and Upper Neopleistocene end-moraine complexes A. Gizhiga Plain and the Taigonos Peninsula: 13 - bottom moraine: 1, 2 - Upper Neopleistocene: 1 - Sartan, 2 -Zyryan; 3 - Middle Neopleistocene; 4 - end moraine ridges: $a$-Sartan, $\sigma$ - Zyryan, 6 - Middle Neopleistocene; 5 - line of the main watershed of the Taigonos Peninsula; 6 - geomorphological boundaries: $a$ - established, $\sigma$-assumed. Б. The lower Paren R.: 1 - moraine lake; 2 -alluvial deposits; 3 -moraine complex: $a$ - bottom moraine, $\sigma$ - end-moraine ridge fragments; 4 - areas of low moun-

tains not covered with ice. B. The Lower Anadyr plain: end-moraine ridges - Upper Neopleistocene (1), Middle Neopleistocene (2)

наиболее протяженных на Северо-Востоке Азии - около 300 км. Он формировался из горнодолинных ледников, спускавшихся с хр. Пекульней и Чукотского нагорья.
Широкая распространенность средне-неоплейстоценовых ледниковых комплексов в гляциальных районах Сунтар-Хаята, Чукотском и Колымо-Охотском, присутствие эрратических 
валунов в сквозных долинах и на поверхностях междуречий позволяют предположить, что это оледенение в горных сооружениях ОхотскоКолымского водораздела было сетчатым, а местами - горно-покровным (Ананьев и др., 1984; Глушкова, 2015).

\section{ВЕРХНЕ-НЕОПЛЕЙСТОЦЕНОВЫЕ ЛЕДНИКОВЫЕ КОМПЛЕКСЫ}

На территории Северо-Востока России следы двух последних поздне-неоплейстоценовых оледенений хорошо выражены в рельефе и запечатлены в широко распространенных экзарационных, моренных и водно-ледниковых образованиях. Экзарационные формы рельефа представлены трогами разной протяженности, крупными карами, другими типичными проявлениями ледникового воздействия на горные склоны и днища долин. Широко развиты также холмисто-грядовый рельеф основной морены, конечно-моренные валы и гряды, часто образующие крупные амфитеатры, флювиогляциальные поля (рис. 3). Мно-
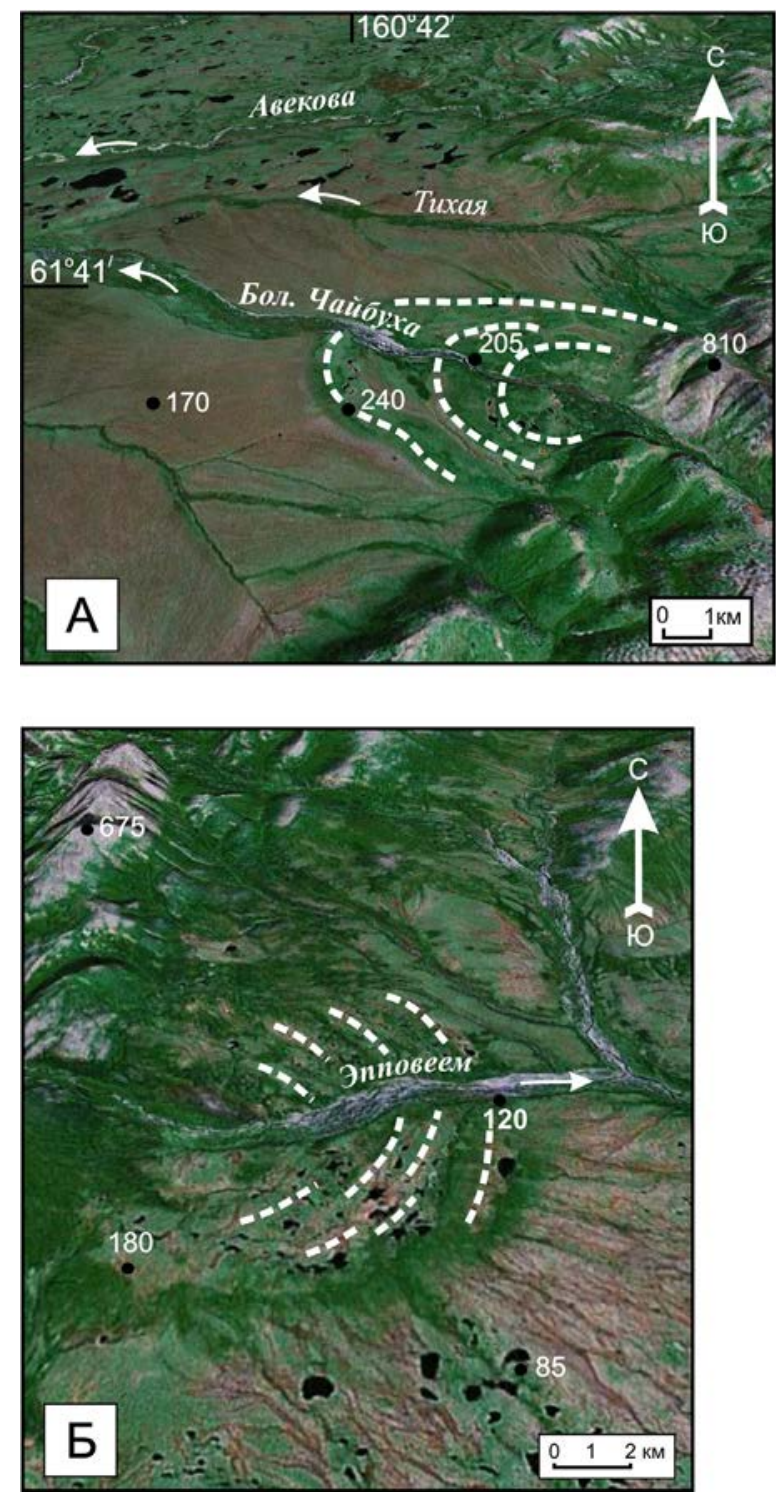

гие исследователи здесь уверенно устанавливают два самостоятельных ледниковых комплекса (сопоставляемых с МИС 2 и МИС 4), которые отчетливо различаются по занимаемой геоморфологической позиции, степени сохранности форм, а также по масштабам распространения и времени формирования. Они соответствуют зырянскому и сартанскому оледенениям Сибири, выделенным В. Н. Саксом (1953; Глушкова, 1984, 1996). К настоящему времени в результате изучения ледниковых комплексов в хр. Черского и в Колымском нагорье получены данные, которые указывают на то, что максимум последнего неоплейстоценового оледенения приходится на вторую половину каргинского времени (Галанин, 2012). Эти данные ставят вопрос о метахронности (неодновременности) поздне-неоплейстоценовых оледенений в ледниковых районах Северо-Востока России.

Гляциальные комплексы первого поздненеоплейстоценового оледенения $\left(Q_{\text {III }}{ }^{2}\right)$ образуют ареалы, значительно уступающие по размерам средне-неоплейстоценовым.

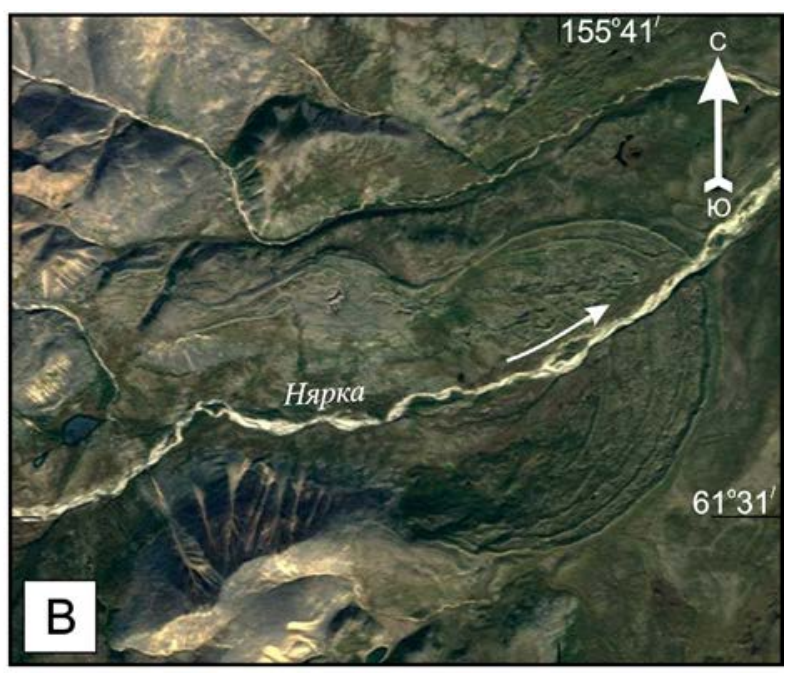

Puc. 3. Верхне-неоплейстоценовые конечноморенные амфитеатры в Северном Приохотье. Зырянские. П-ов Тайгонос: северо-западный (А) и юго-восточный (Б) склоны Тайнынотского хребта. Сартанский: горы Хэл-Урэкчэн (В)

Fig. 3. Upper Neopleistocene end-moraine amphitheaters in the Northern Priokhotye. Zyryan. The Taygonos Pen.: the northwestern (A) end southeastern (Б) slopes of the Taynynot Range. Sartan: the Khal Urekchen Mountains (B) 
Они обычно представлены основной мореной, а также крупными амфитеатрами, состоящими из нескольких конечно-моренных гряд длиной до 30 км и высотой до 60 м. Максимальное расстояние их от области питания достигает 100 км. Гребни и склоны валов сильно переработаны эрозионными и криогенными процессами. С внешней стороны к фронтальным грядам примыкают обширные зандровые поля с широким развитием термокарстовых процессов. В наиболее высокогорных областях Северо-Востока России (горная система Черского и хр. Сунтар-Хаята, центральная часть Корякского нагорья) оледенение имело сетчатый характер. В районах, примыкающих к побережьям Берингова (Нижне-Анадырская низменность) и Охотского моря (Ямская, Гижигинская низменности), реконструируются мощные ледники подножий (Glushkova, 2001; Глушкова, 2015).

В северной части Нижне-Анадырской низменности для зырянских ледниковых комплексов характерно широкое распространение холмисто-грядового и холмисто-западинного рельефа основной морены с ледниковыми озерами (см. рис. 2,В). На этом фоне выделяются крупные терминальные комплексы, представленные дугообразными конечно-моренными валами и грядами, длина которых достигает 20-30 км, ширина $1.5-4.5$ км, высота - от 20 до 60 м.

Анализ ледниковых образований, распространенных в бассейне среднего течения р. Танюрер и Канчалан, показал, что северная часть НижнеАнадырской низменности перекрывалась ледниками первого поздне-неоплейстоценового оледенения. На низменности формировался огромный ледник подножий. Наблюдения на небольших возвышенностях на низменности показали, что мощность льда в средней части ледника была не меньше 150-200 м. В бассейне среднего течения р. Танюрер установлено несколько крупных конечно-моренных валов и расположенных между ними небольших, часто сближенных гряд, что свидетельствует о длительном и динамичном максимуме ледника (Глушкова, Гуалтиери, 1998).
В Анюйско-Олойском гляциальном районе проблема разделения ледниковых комплексов до сих пор остается слабо изученной. По морфологическим признакам выделяются два поздненеоплейстоценовых ледниковых комплекса. В зырянское время на северо-западе Чукотки возникали 2 крупных ледниковых ареала и несколько обособленных ледниковых центров. Северный ареал занимал горы Пырканай и Раучуанский хребет. Южный, более обширный, охватывал Чуванские горы, Илирнейский кряж и горные массивы в верхнем течении рр. Большой Анюй и Малый Анюй. Ледниковые образования представлены сильно разрушенными конечными моренами, холмисто-грядовым рельефом основной морены на днищах долин. Зырянские ледники не только заполняли большинство долин, но и перетекали через низкие водораздельные седловины из одного бассейна в другой. Наиболее мощные и протяженные дендритовые ледники возникали на южном склоне Илирнейского кряжа: Тытыльваамский ледник имел длину 60 км, а Илирнейский - 65 км. Длина ледников северного склона варьировала от 25 до 40 км (Glushkova, 2001).

Гляциальные центры последнего поздненеоплейстоценового оледенения $\left(Q_{\text {III }}{ }^{4}\right)$

Гляциальные комплексы последнего поздненеоплейстоценового оледенения - сартанского наиболее ясно выражены в современном рельефе. Они распространены на площадях, в 2-3 раза меньших, чем у предшествовавшего. Анализ расположения форм этого ледникового комплекса показал, что в основном оледенением были охвачены наиболее высокие горные районы, где отчетливо обособляются локальные гляциальные центры. Его конечно-моренные формы отличаются хорошей морфологической выраженностью и слабо переработаны последующими экзогенными процессами. Данные палинологического и радиоуглеродного анализов позволяют определить их возраст как сартанский (см. таблицу).

\section{Таблица. Радиоуглеродные датировки осадков ледникового комплекса}

Table. Radiocarbon dating of the glacial complex sediments

\begin{tabular}{|l|l|l|l|l|}
\hline $\begin{array}{c}\text { Гляциальный } \\
\text { район }\end{array}$ & $\begin{array}{l}\text { Местоположе- } \\
\text { ние изученных } \\
\text { объектов }\end{array}$ & \multicolumn{1}{|c|}{${ }^{14}$ С возраст } & Генезис осадков & \multicolumn{1}{|l|}{ Источник данных } \\
\hline Черский & $\begin{array}{l}\text { хр. Бол. Ан- } \\
\text { начаг }\end{array}$ & $\begin{array}{l}13040 \pm 105, \mathrm{WNG}-958 / \mathrm{AA}-6884 \\
21860 \pm 235, \mathrm{WNG}-819 / \mathrm{AA} 5813\end{array}$ & $\begin{array}{l}\text { Донные осад- } \\
\text { ки моренных } \\
\text { озер }\end{array}$ & $\begin{array}{l}\text { Позднечетвертичные..., } \\
2002\end{array}$ \\
\hline \multirow{2}{\text{Чукотский}}{} & $\begin{array}{l}\text { хр. Пекуль- } \\
\text { ней, р. Куй- } \\
\text { вивеем }\end{array}$ & $\begin{array}{l}17000 \pm 360, \mathrm{MAG}-1502 \\
16860 \pm 260, \mathrm{GX}-21531-\mathrm{AMS} \\
21500 \pm 2750, \mathrm{GX}-21525\end{array}$ & $\begin{array}{l}\text { Флювиогляци- } \\
\text { альные осадки }\end{array}$ & $\begin{array}{l}\text { Глушкова, 1996; Glush- } \\
\text { kоva, 2001 }\end{array}$ \\
\hline
\end{tabular}

Примечание. Аналитические лаборатории. МАГ - СВКНИИ ДВО РАН; WHG - Arizona lab.; GX - Geochron lab. Kruger Enterprises, Inc. 

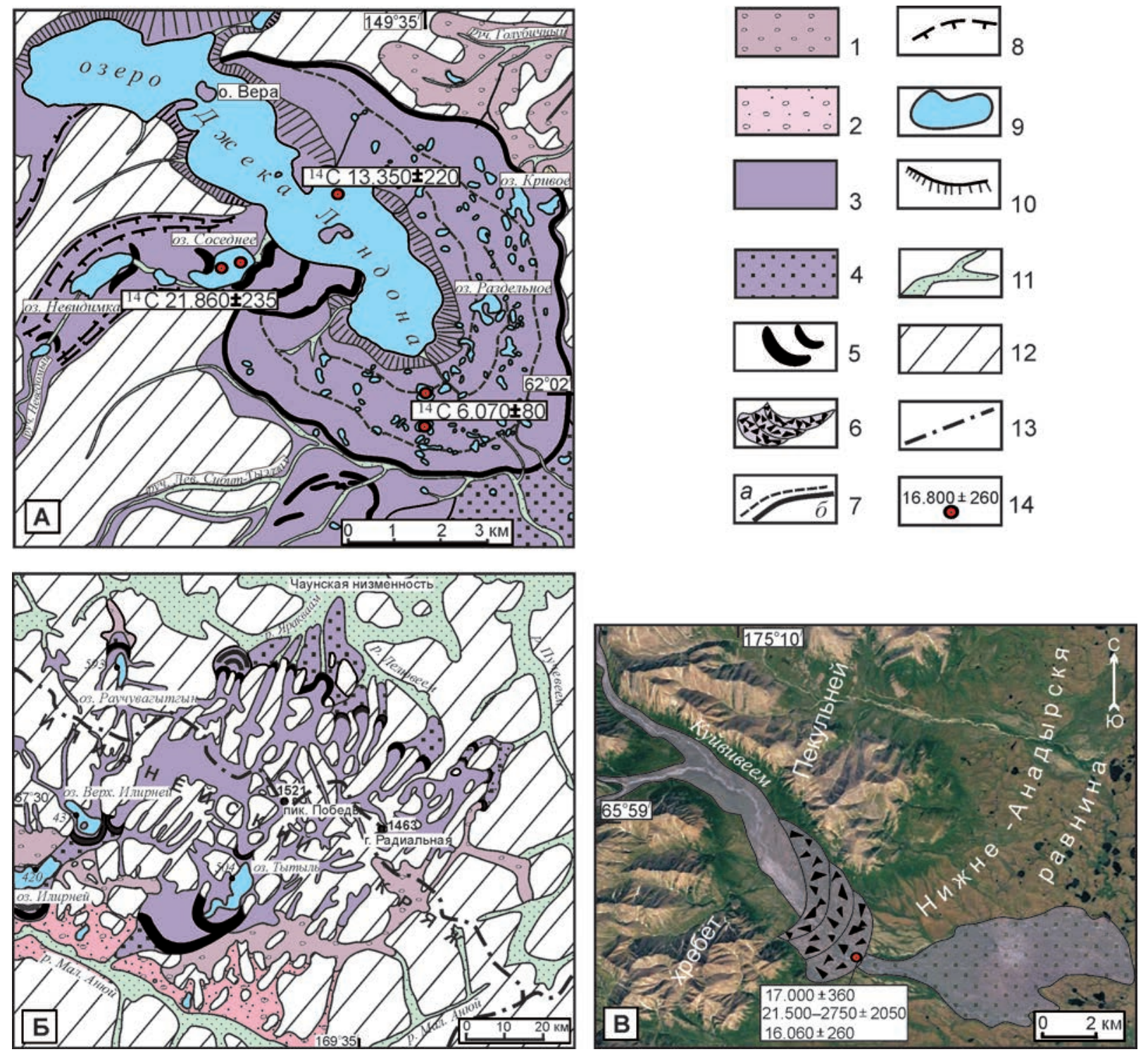

Pис. 4. Верхне-неоплейстоценовые гляциальные центры: А - хр. Анначаг, Б - Илирнейский кряж, В - хр. Пекульней, р. Куйвевеем. Формы ледникового рельефа. Зырянские: 1 - основная морена; 2 - флювиогляциальные поля. Сартанские: 3 - основная морена, 4 - флювиогляциальные поля, 5 - отдельные конечно-моренные валы, 6 - сомкнутые конечно-моренные валы; 7 - гребни внутренних валов $(a)$ и внешний вал конечно-моренного комплекса оз. Джека Лондона (б); 8 - плечи трогов; 9 - ледниковые озера; 10 - абразионные берега озер. Прочие: 11 - речные русла; 12 - горные склоны, не покрывавшиеся ледниками; 13 - линия водораздела; 14 - результаты радиоуглеродного датирования коррелятных отложений

Fig. 4. Upper Neopleistocene glacial centers: A - Annachag Range, Б - Ilirney Range, B - Pekulney Range, Kuiviveyem R. Forms of glacial relief. Zyryan: 1 - basal moraine; 2 - fluvioglacial fields. Sartan: 3 - basal moraine, 4 fluvioglacial fields, 5 - individual end-moraine ridges, 6 - connected end-moraine ridges; 7 - crests of the inner ridges (a) and the outer ridges of the Lake Jack London end-moraine complex (6); 8 - trog shoulders; 9 - glacial lakes; 10 abrasive lake shores. Other: 11 - river channels; 12 - mountain slopes not covered with glaciers; 13 - watershed line; 14 - results of radiocarbon dating for correlative deposits

В гляциальном районе хр. Черского сартанские терминальные комплексы крупных размеров установлены в различных его частях. В центральной части хребта на эпоху максимального распространения сартанских ледников реконструируется в основном горно-долинное и сетчатое и в меньшей степени - горно-покровное оледенение. Самые крупные долинные ледни- ки (Буордахский, Тирехтяхский и др.) возникали в наиболее высокой (2500-3000 м) центральной части хр. Улахан-Чистай (см. рис. 1). В максимум оледенения они достигали длины 60-100 км (Шейнкман, 1987). Их максимальное продвижение фиксируется мощными конечноморенными грядами в пределах Момской впадины на абсолютной высоте 700-800 м, что на 
800-1000 м ниже окончаний современных ледников.

Наиболее крупный конечно-моренный комплекс оставлен тирехтяхским ледником, который стекал по долине р. Тирехтях (левый приток р. Мома) на поверхность Момской межгорной впадины. Здесь наблюдаются обширные амфитеатры, состоящие из серии сближенных конечноморенных гряд, мощных валов, наложенных один на другой или отстоящих на небольшие расстояния. Протяженность внешней дуги, перегораживающей долину р. Тирехтях, около 30 км. Длина внутренних напорно-насыпных моренных гряд до 20 км, высота до 150 м. Наиболее крупные из них сопровождаются подпрудными ледниковыми озерами. Этот комплекс находится на расстоянии 70 км от области питания (Glushkova, 2001; Глушкова, 2015).

Сложные конечно-моренные комплексы последнего поздне-неоплейстоценового оледенения изучены также в южной части хр. Черского, на Чукотке в Илирнейском кряже, хр. Раучуанский, Анюйский, Пекульней, а также в северовосточной части Корякского нагорья.

Анначагский гляциальный центр расположен в 370 км к юго-востоку от упомянутого выше ледникового узла хр. Улахан-Чистай. Абсолютная высота хр. Анначаг достигает 2000-2200 м. Реконструированы границы сартанского оледенения, а также основные параметры, пути движения наиболее крупных ледников. С западного склона хр. Бол. Анначаг стекал Восьмиозерный ледник, который в максимальную фазу имел длину 21 км. Его продвижение зафиксировано обширной конечно-моренной грядой, перегородившей долину р. Эльгення с образованием одноименного крупного подпрудного озера длиной 4.3 км. Моренная гряда протягивается с севера на юг на расстояние 13 км, почти повсеместно имеет узкий гребень - 1020 м, что указывает на ее молодость. Высота гряды возрастает с юга на север от 60-70 до $200 \mathrm{M}$.

С восточного склона хребта ледник спускался по долине руч. Пурга. Он заполнял межгорную впадину, на поверхности которой оставил после себя обширный конечно-моренный комплекс, включающий оз. Джека Лондона, которое с юга окружено круто изогнутым конечно-моренным валом протяженностью 15 км, шириной 2.6 км, высотой 110-120 м. Максимальная длина ледника Пурга составляла 26.5 км (Позднечетвертичные..., 2002; Глушкова, 2015).

На северо-западной Чукотке сартанское оледенение по площади в несколько раз уступало зырянскому. Оно было рассредоточено в 10 обособленных горных узлах, тяготеющих к центральным, наиболее возвышенным частям Рау- чуанского, Анюйского хребтов и Илирнейского кряжа. В горных массивах северной части района возникали лишь короткие долинные и каровые ледники. По долине р. Раучуа (басс. Чаунской губы) ледник выдвигался на 25 км. Разгрузка происходила в небольшой внутригорной котловине. В рельефе хорошо выражены дуги четырех сближенных конечно-моренных валов, имеющих длину от 3 до 6 км, ширину 0.3-1.7 км и высоту 40-80 м.

Илирнейский гляциальный центр. В 150 160 км к югу от Чаунской губы расположены разнообразные ледниковые комплексы Илирнейского кряжа, который протягивается с запада на восток на 140 км при ширине 50 км. В осевой части кряжа рельеф альпинотипный, изобилует многочисленными и разнообразными формами ледниковой аккумуляции и экзарации. Средняя абсолютная высота горных вершин 1300-1500 м, максимальная - г. Двух Цирков составляет 1853 м. С юга кряж ограничен широкой плоской долиной p. Мал. Анюй, а на севере низкогорные отроги кряжа плавно переходят в холмистую равнину, смыкающуюся с Чаунской низменностью. Для южного склона этого ледникового узла характерны крупные ледниковые озера: Верх. Илирней, Илирней и Тытыль, которые расположены с внутренней стороны обширных конечно-моренных амфитеатров. Озеро Тытыль заполняет долину p. Тытлиутин, стекающей с осевой части кряжа. Абсолютная высота уреза воды озера 504 м, его длина 18.8 км, максимальная ширина -4.5 км. С юга озеро окаймляется крупными конечноморенными грядами дугообразной формы. Длина внешней гряды превышает 15 км, ширина до 3 км и относительная высота над рекой - 100160 м. Конечно-моренный амфитеатр, состоящий из пяти гряд, оставлен долинным ледником длиной 34 км. На выходе в широкую долину р. Мал. Анюй этот ледник сливался с тремя ледниками, спускавшимися по долинам рр. Тытлиутин, Тытыльваам и Луковая. Слабая степень разрушенности гряд, наличие островов и зазубренных мысов в озере свидетельствуют в пользу недавнего (сартанского) времени формирования данного конечно-моренного комплекса.

Хребет Пекульней. В бассейне верхнего течения р. Танюрер на восточном склоне хр. Пекульней сартанский комплес имеет ограниченное распространение по сравнению с зырянским, он локализуется в верховьях долин. Его конечные морены редко выходят в предгорья. Ледниковые образования комплекса наиболее выразительны в бассейне р. Куйвивеем, правого притока р. Танюрер. Здесь установлено 28 ледниковых каров, днища которых находятся на высоте в среднем около 600-700 м. На расстоянии 20 км от истока долина реки перегорожена тремя сближенными 
крутыми дугами моренных гряд высотой от 1520 до 130 м, фиксирующих максимальное продвижение ледника. В отложениях сопряженной с внешним моренным валом флювиогляциальной равнины получены две радиоуглеродные даты: $16860 \pm 260$ и $21500 \pm 2750$ л. н. (Brigham-Grette et al., 2003), которые указывают на позднесартанский возраст гляциального комплекса.

Чукотский полуостров. На северо-западе Чукотского полуострова, на Ванкаремской низменности выделены три стадиальные гряды последнего оледенения (Лаухин и др., 2006). В указанной работе отмечается «широкое развитие свежего ледникового рельефа, закартированного на Ванкаремской низменности», но, к сожалению, не приведено данных о его морфологии и морфометрии. Стадиальные гряды авторами коррелируются со вскрытыми в разведочных шахтах моренами, лежащими на аллювии, из которого получены ${ }^{14} \mathrm{C}$-даты 40.1-39.3 тыс. лет.

Корякское нагорье. В результате анализа предыдущих работ (Дегтяренко, 1984; Глушкова и др., 1987) и новых данных по изучению скульптурных и аккумулятивных гляциальных форм установлено, что ледниковые образования на большей части Корякского нагорья принадлежат двум последним оледенениям позднего неоплейстоцена. Наиболее полно они изучены на северовосточном склоне Корякского хребта в районе хр. Кэнкэрэн и оз. Майниц (см. рис. 1). В этом районе в альпинотипном среднегорье в ледниковых долинах присутствуют крутосклонные моренные холмы и гряды, сложенные массивной грубообломочной мореной. Гряды длиной 0.8-1.5 км и высотой 20-40 м имеют ясно выраженные острые гребни. Наиболее крупный конечно-моренный комплекс выдвинут в предгорья хр. Кэнкэрэн на южную окраину НижнеАнадырской низменности. Он оставлен ледником, который стекал на север по долине р. Ныгчеквеем от ее истоков на расстояние 60 км. Длина конечно-моренного вала около 11 км, ширина около 6 км, высота отдельных гряд - 120 140 м. Часты глубокие западины, котловины, многочисленны разнообразные по форме озера. На разных участках морены получена серия дат по ${ }^{36} \mathrm{Cl}$, средние значения которых колеблются в интервале 15-16 тыс. л. н. , что соответствует концу сартанского гляциала. Фрагменты конечно-моренных гряд сохранились также в долине р. Гытгывеем. Четыре из них перегораживают крупное проточное оз. Майниц длиной около 20 км, шириной до 5 км и глубиной до 130 м. Длина моренной гряды, подпруживающей оз. Майниц с севера, более 3 км, ширина 1.5-2 км. По валунам, обнажающимся на гребне одной из гряд, получены две даты (по $\left.{ }^{36} \mathrm{Cl}\right): 10.08 \pm 0.85$ и $19.51 \pm$ 2.27 тыс. л. н. (Глушкова, Гуалтиери, 1998; Stauch,
Gualtieri, 2008). Кроме того, из донных осадков оз. Патриция, расположенного в понижении конечно-моренного вала, подпруживающего оз. Майниц, получена радиоуглеродная дата 15810 л. (Anderson, Lozhkin, 2008). Приведенные даты указывают на заключительную фазу последнего оледенения.

\section{ОБСУЖДЕНИЕ}

Приведенные материалы позволяют высказать некоторые общие соображения относительно развития оледенений на территории СевероВостока и роли неотектонических и климатических факторов в этом процессе. Позднеэоплейстоценовое и ранне-неоплейстоценовое оледенения, соответствующие глобальным эпохам похолодания, развивались в локальных наиболее поднятых горных массивах на фоне общего равновесного конэрозионного развития низкогорного рельефа в бассейнах рр. Колыма и Индигирка. Ледники возникали на ограниченных площадях только в тех районах, где поверхность гор касалась хионосферы. Такие участки приурочены к центральной и юго-восточной части хр. Черского, где отмечаются резко дифференцированные неотектонические движения, которые обусловили формирование локальных поднятий и межгорных впадин. Ледники стекали на поверхности впадин и разгружали морены, которые становились частью континентальных толщ межгорных впадин.

Широкое распространение ледников в средненеоплейстоценовую эпоху четко коррелирует с увеличением в это время высоты горных сооружений, которое установлено по многим признакам в разных районах Северо-Востока. К тому времени относится активное воздымание хр. Верхоянский, Черский, а также хребтов и нагорий Охотско-Чукотской горной области (Спектор, Спектор, 2008; Смирнов, Глушкова, 2018). Рост высоты гор привел к тому, что наиболее высокие горные массивы достигли хионосферы, в связи с чем во многих горных узлах образовались обширные области питания ледников. Таким образом, резкое увеличение темпа поднятий горных сооружений Северо-Востока России обусловило благоприятные предпосылки для развития оледенения в средне-неоплейстоценовую эпоху похолодания.

В континентальных и прибрежных горных сооружениях существовала заметная асимметрия в размерах последнего поздне-неоплейстоценового оледенения. Масштабы оледенения уменьшались в направлении от прибрежных районов к континентальным, что прямо указывает на решающую роль морских влагонесущих потоков при формировании оледенения. Вместе с тем, независимо от различающихся местных климатических условий в разных районах Северо-Востока, последнее поздне-неоплейстоценовое оледенение 
имело ограниченные масштабы. Необходимо отметить также, что в самых высоких горах расчлененного среднегорья оба оледенения (зырянское и сартанское) развивались примерно по одному типу. В то же время в низкогорных районах с широким развитием плоскогорий различались не только масштабы, но и типы оледенения.

Резкое уменьшение площадей последнего оледенения, по сравнению с предыдущим в некоторых горных районах Охотко-Чукотской области (например, в Колымском нагорье и Анадырском плоскогорье), объясняется тем, что при повышении снеговой границы вследствие иссушения климата в этих районах из нивально-гляциальной зоны одновременно выходили обширные близкие по абсолютным высотам территории верхнего пояса гор. В то же время в высокогорных узлах верхний ярус не выходил из пределов хионосферы, продолжая оставаться областью питания для горно-долинных ледников. Таким образом, последовательное уменьшение масштабов поздненеоплейстоценовых оледенений определялось существенными изменениями климата, который с начала позднего неоплейстоцена имел тенденцию к иссушению и похолоданию (Верховская, 1986). Малое количество влаги привело к тому, что накопление снега и льда происходило только в наиболее высоких областях питания, где твердые осадки выпадали на протяжении всего года, а не только в зимние периоды, и к сильному и неравномерному сокращению области питания ледников. Одновременно на фоне такого изменения климата еще более проявился орогенный фактор формирования ледников. В высокогорных внутриконтинентальных районах с обширной областью ледникового питания максимальная протяженность ледников в единичных случаях достигала 100 км (хр. Улахан-Чистай). А в низкогорных, даже расположенных вблизи морских побережий Охотского и Берингова морей, длина ледников редко превышала 20 км.

\section{ЗАКЛЮЧЕНИЕ}

По сумме имеющихся данных относительно развития неоплейстоценовых оледенений на Северо-Востоке России можно сделать следующие выводы:

на Северо-Востоке России уверенно выделяютя три неоплейстоценовых конечно-моренных комплекса, которые различаются положением в рельефе, расстоянием до областей питания и степенью постгенетических пребразований;

на возникновение оледенений и их распространение на обширной территории СевероВостока России, кроме климатических условий, решающее влияние оказывали локальные орографические факторы; самые ранние оледенения - поздне-эоплейстоценовое и ранне-неоплейстоценовое имели локальное рапространение преимущественно в наиболее поднятых частях хр. Черского. Их следы представлены только в виде морен, заключенных в осадках межгорных впадин. Ледниковые формы этого возраста в рельефе гор и равнин не установлены;

средне-неоплейстоценовое оледенение было самым крупным и по площади, и по длине отдельных ледников, которые часто заполняли межгорные впадины. По времени это оледенение совпадает с этапом активизации восходящих тектонических движений, в течение которого оформился высотный уровень гор, благоприятный для возникновения крупномасштабного оледенения. Совпадение двух благоприятных для развития оледенения факторов - орогенического и климатического - определило горно-долинный сетчатый, местами горно-покровный тип оледенения;

первое поздне-неоплейстоценовое оледенение (зырянское) значительно уступало по всем параметрам предыдущему, но оно также распространялось во впадины, образуя в предгорьях крупные ледники подножий;

последнее поздне-неоплейстоценовое оледенение (сартанское) по масштабам было во много раз меньше зырянского. Оно, как правило, не выходило за пределы верхних ярусов горных сооружений.

Таким образом, в течение эоплейстоцена, раннего и среднего неоплейстоцена ведущим фактором распространения оледенений на СевероВостоке России, их масштабов и морфологии был орографический - высота гор. Начиная с зырянского времени, наряду с орографическим, главным фактором сокращения масштабов оледенений стал климатический - иссушение климата в последние ледниковые эпохи.

Одной из главных задач дальнейших исследований четвертичных оледенений Северо-Востока России является определение изотопного возраста конечно-моренных комплексов, так как только этими формами ледникового рельефа реально фиксируются максимум оледенения и стадии его деградации.

Другая важная задача - изучение локального влияния неотектонических движений на возникновение оледенения в горных сооружениях и на ингрессию (регрессию) моря в прибрежных низменностях.

\section{ЛИТЕРАТУРА}

Ананьев Г. С., Ананьева Э. Г., Пахомов А. Ю. Четвертичные оледенения Северо-Западного Приохотья // Плейстоценовые оледенения Востока Азии. Магадан : СВКНИИ ДВНЦ РАН СССР, 1984. С. 43-56.

Баранова Ю. П. К истории развития рельефа Нижне-Анадырской низменности и окружающих ее 
гор в четвертичном периоде // Геология и геофизика. 1960. № 12. С. 72-85.

Васьковский А. П. Краткий очерк растительности, климата и хронологии четвертичного периода в верховьях рек Колымы, Индигирки и на северном побережье Охотского моря // Ледниковый период на территории европейской части СССР и Сибири. Москва : Изд-во МГУ, 1959. С. 510-556.

Верховская Н. Б. Плейстоцен Чукотки. Владивосток : ДВНЦ АН СССР, 1986. 112 с.

Веснин В. В., Вийра В. И., Карташов И. П. История формирования ледникового рельефа в районе озера Джека Лондона // ДАН СССР. 1962. Т. 147, № 3. C. 2101-2104.

Воскресенский С. С., Чанышева М. Н., Воскресенский И. С., Каревская И. А., Полосухина 3. М. Плейстоценовые оледенения бассейна Колымы // Плейстоценовые оледенения Востока Азии. Магадан : СВКНИИ ДВНЦ АН СССР, 1984. С. 57-65.

Галанин A. A. Возраст последнего ледникового максимума на Северо-Востоке Азии // Криосфера Земли. 2012. Т. 16, № 3. С. 39-52.

Глушкова О. Ю. Конечно-моренные комплексы в Западной Берингии // Чтения памяти академика К. В. Симакова : Материалы докладов Всерос. науч. конф. (Магадан, 24-25 ноября 2015 г.); [отв. ред. Н. А. Горячев]. Магадан : ООО «Типография», 2015. С. 31-33.

Глушкова О. Ю. Морфология и палеогеография позднеплейстоценовых оледенений Северо-Востока СССР // Плейстоценовые оледенения Востока Азии. Магадан : СВКНИИ ДВНЦ АН СССР, 1984. С. 28-42.

Глушкова О. Ю. Отражение климатических ритмов в морфологии рельефа Западной Берингии // Четвертичные климаты и растительность Берингии. Магадан : СВКНИИ ДВО РАН, 1996. С. 94-114.

Глушкова О. Ю. Позднеплейстоценовые оледенения Северо-Востока СССР : автореф. дис. ... канд. геогр. наук. Новосибирск, 1986. 16 с.

Глушкова О. Ю. Позднеплейстоценовые оледенения Берингии // Геология, география и биологическое разнообразие Северо-Востока России : Материалы Дальневосточной региональной конференции, посвященной памяти А. П. Васьковского и в честь его 95-летия (Магадан, 28-30 ноября 2006 г.). Магадан : СВНЦ ДВО РАН, 2006. С. 108-113.

Глушкова О. Ю., Гуалтиери Л. Особенности позднеплейстоценового оледенения северной части Корякского нагорья // Изменение природной среды Берингии в четвертичный период. Магадан : СВКНИИ ДВО РАН, 1998. С. 112-132.

Глушкова О. Ю., Прохорова Т. П. Особенности формирования позднеплейстоценовых оледенений и осадконакопления в бассейне р. Эльгенья (ВерхнеКолымское нагорье) // Четвертичный период СевероВостока Азии. Магадан : СВКНИИ ДВНЦ АН СССР, 1987. C. $68-89$.

Глушкова О. Ю., Прохорова Т. П. Плейстоценовые оледенения Северо-Востока СССР // Палеоклиматы и оледенение в плейстоцене. Москва : Наука, 1989. C. 224-231.

Глушкова О. Ю., Смирнов В. Н. Неоплейстоценовые ледниковые комплексы на Северо-Востоке России / Форум «Наука Северо-Востока России: Фундаментальные и прикладные исследования в Северной
Пацифике и Арктике». Магадан, 5-6 марта 2020 г.; (отв. ред. Н. А. Горячев). Магадан : СВКНИИ ДВО PAH, 2020. C. 23-26.

Глушкова О. Ю., Прохорова Т. П., Дегтяренко Ю. П. Плейстоценовые оледенения и связанные с ними особенности осадконакопления и перестроек гидросети в Корякском нагорье // Четвертичный период Северо-Востока Азии. Магадан : СВКНИИ ДВНЦ АН СCCP, 1987. C. 33-54.

Дегтяренко Ю. П. Масштабы современного и четвертичных оледенений и четвертичных оледенений Корякского нагорья и Восточной Чукотки // Плейстоценовые оледенения Востока Азии. Магадан : СВКНИИ ДВНЦ АН СССР, 1984. С. 66-76.

Иванов В. Ф. Четвертичные отложения побережья Восточной Чукотки. Владивосток : ДВНЦ АН СССР, 1986. $140 \mathrm{c}$.

Клюкин Н. К. Климатическое районирование // Север Дальнего Востока. Москва : Наука, 1970. С. 111119.

Колосов Д. М. Проблемы древнего оледенения Северо-Востока СССР // Тр. ГГУ ГУСМП. Ленинград, 1947. Вып. 30. 173 с.

Лаухин С. А., Цзян Чжсимин, Пушкарь В. С., Черепанова М. В. Последнее оледенение на севере Восточной Чукотки и палеоокеанография Северной Пацифики // Доклады Академии наук. 2006. Т. 411, № 3. С. 405-409.

Ложкин А. В., Андерсон П. М., Белая Б. В., Глушкова О. Ю., Кожевникова М. В., Котова Л. Н. Палинологическая характеристика и радиоуглеродные датировки осадков озера Эльгення, Верхняя Колыма // Четвертичные климаты и растительность Берингии. Магадан : СВКНИИ ДВО РАН, 1996. С. 50-64.

Ложкин А. В., Андерсон П. М., Браун Т. А., Важенина Л. Н., Глушкова О. Ю., Котов А. Н., Матросова T. B. Оледенение Анадырской низменности (по данным осадков озер) // Страницы четвертичной истории Северо-Восточной Азии. Магадан : СВКНИИ ДВО PAH, 2005. C. 4-22.

Новейшие отложения и палеогеография плейстоцена Чукотки. Москва : Наука, 1980. 295 с.

Петров О. М. Стратиграфия и фауна морских моллюсков четвертичных отложений Чукотского полуострова. Москва : Наука, 1966. 290 с.

Позднечетвертичные растительность и климаты Сибири и Российского Дальнего Востока (палинологическая и радиоуглеродная база данных) / ред. П. М. Андерсон, А. В. Ложкин. Магадан : СВНЦ ДВО РАН, 2002. 369 c.

Сакс B. Н. Четвертичный период в Советской Арктике. Ленинград : Мин-во мор. и реч. флота, 1953. 627 с.

Смирнов В. Н., Глушкова О. Ю. Ледниковые комплексы на полуострове Тайгонос // Геоморфология и палеогеография полярных регионов : Материалы совместной междунар. конф., симпозиума «Леопольдина» и совещания рабочей группы INQUA Peribaltic. Санкт-Петербург, СПбГУ, 9-17 сент. 2012 года / отв. ред. И. А. Жиров, В. Ю. Кузнецов, Д. А. Субетто, Й. Тиде. Санкт-Петербург, 2012. С. 226-229.

Смирнов В. Н., Глушкова О. Ю. Среднеплейстоценовая тектоническая активизация в ВерхояноЧукотской области горообразования // Проблемы тектоники и геодинамики земной коры и мантии : Мате- 
риалы L Тектонического совещания. Москва : ГЕОС, 2018. T. 2. C. 199-202.

Спектор В. Б., Спектор В. В. Режим возрожденного горообразования Верхояно-Колымской горной области // Общие и региональные проблемы тектоники и геодинамики. Материалы XLI Тектонического совещания. Москва : ГЕОС, 2008. Т. 2. С. 291-294.

Шейнкман В. С. Гляциология и палеогляциология горной системы Черского и сопредельных районов Северо-Востока СССР. Москва, 1987. 154 с.

Шило Н. А. Четвертичные отложения Яно-Колымского золотоносного пояса, условия и этапы их формирования // Материалы по геологии и полезным ископаемым Северо-Востока СССР. Магадан : Кн. изд-во, 1961. Вып. 66. 136 с.

Шило Н. А., Ложкин А. В., Андерсон П. М., Белая Б. В., Стеиенко Т. В., Глушкова О. Ю., БригхемГретте Дж., Меллес М., Минюк П. С., Новачек Н., Форман С. Первая непрерывная пыльцевая летопись изменений климата и растительности Берингии за последние 300 тысяч лет // ДАН. 2001. Т. 376, № 2. C. 231-234.

Янина T. А. О новой стратиграфической шкале четвертичной системы // Вестник Московского ун-та. Сер. 5. География. (1). 2014. С. 85-87.

Brigham-Grette J., Gualtieri L., Glushkova O., Hamilton T., Mostoller D., Kotov A. Chlorine-36 and ${ }^{14} \mathrm{C}$ chronology support a limited last glacial maximum across Central Chukotka, Northeastern Siberia, and no
Beringian ice sheet // Quaternary Research. 2003. 59. P. 386-398.

Glushkova O. Yu. Geomorphological correlation of Late Pleistocene glacial complexes of Western and Eastern Beringia // Quaternary Science Reviews. 2001. 20. P. 405-417.

Glushkova O. Yu. Late Pleistocene glaciation in NorthEast Asia // Quaternary glaciations - extent and chronology: A closer look. Developments in North-East Asia / Ed. J. Ehlers, P. L. Gibbard, P. D. Hughes. Amsterdam, the Netherlands. 2011. Vol. 15. P. 865-875.

Gualtieri L., Brigham-Grette J., Glushkova O. The exent, style and chronology of glaciation in Northeast Russia / XYI INQUA Congress Abstract No 55200, session Quaternary Environments of the Eurasian North. Programs with Abstracts. 2003. P. 196.

NovaczykN. R., Minyuk P., Melles M., Brigham-Grette J., Glushkova O. Yu. , Nolan M., Lozhkin A. V., Stetsenko T. V., Anderson P. M., Forman S. L. Magnetostratigraphic results from impact crater Lake El'gygytgyn, Northeastern Siberia: a 300 kyr long high-resolution terrestrial paleoclimatic record from the Arctic // Geophysical Journal International. 2002. Vol. 150, No. 1. P. 109-126.

Stauch G., Gualtieri L. Late Quaternary glaciations in Northeastern Russia // Journal of Quaternary Science. 2008. 23 (6-7). P. 545-558.

Stauch G., Lehmkuhl F., Frechen M. Luminescence chronology from the Verkhoyansk Mountains (NorthEastern Siberia) // Quaternary Geochronology. 2007. 2. P. 255-259.

Поступила в редакциюю 24.03.2021 2.

Поступила после доработки 20.04.2021 2.

\title{
RECONSTRUCTION OF THE SCALE AND MORPHOLOGICAL PECULIARITIES OF PLEISTOCENE GLACIATIONS IN NORTH-EAST RUSSIA
}

\section{O. Yu. Glushkova, V. N. Smirnov}

\author{
North-East Interdisciplinary Scientific Research Institute n. a. N. A. Shilo, FEB RAS, Magadan
}

Based on the currently available data, it has been established that the earliest glaciations occurred in the Late Eopleistocene and at the end of the Early Neopleistocene. They had local distribution in the most uplifted parts of the Chersky Range. Their traces are presented in the form of moraines enclosed in sediments of intermontain depressions. Glacial forms of this age have not been identified in the relief of mountains and plains in the North-East of Russia. The Middle Neopleistocene glaciation was the largest, both in area and length of individual glaciers. It was mountain-valley and reticulated; in some areas, mountain-cover. Its time coincides with the stage of activation of the ascending neotectonic movements in the Middle Neopleistocene. Traces of the last two Late Neopleistocene glaciations are well expressed in the relief in widespread exaration, moraine, and fluvioglacial complexes. The first Late Neopleistocene glaciation (Zyryan) was significantly inferior to the one occurred in the Middle Neopleistocene, in all parameters, but it also left large amphitheaters of terminal moraines in the foothill belts. Glacial complexes of the last Late Neopleistocene glaciation are widespread in areas $2-3$ times smaller than the previous one and, as a rule, are located within its contours.

Keywords: Neopleistocene, glaciers, end-moraine forms, glacial regions, North-East Russia. 


\section{REFERENCES}

Ananyev, G. S., Ananyeva, E. G., Pakhomov, A. Yu., 1984. Quaternary Glaciations of the Northwest Priokhotye, Pleistocene Glaciations in the East of Asia. Magadan, SVKNII DVNC AN USSR. 43-56 [In Russian].

Baranova, Yu. P., 1960. On the History of the Development of the Relief in the Lower Anadyr Lowland and the Surrounding Mountains in the Quaternary, Russian Geology and Geophysics. 12, 72-85 [In Russian].

Brigham-Grette, J., Gualtieri, L., Glushkova, O., Hamilton, T., Mostoller, D., Kotov, A., 2003. Chlorine36 and ${ }^{14} \mathrm{C}$ Chronology Support a Limited Last Glacial Maximum Across Central Chukotka, Northeastern Siberia and No Beringian Ice Sheet, Quaternary Research. 59, 386-398.

Galanin, A. A., 2012. Age of the Last Glacial Maximum in Northeast Asia, Earth's Cryosphere. 16, 3, 39-52 [In Russian].

Glushkova, O. Yu., 1984. Morphology and Paleogeography of the Late Pleistocene Glaciations in the NorthEast of the USSR, Pleistocene Glaciations of the East of Asia. Magadan, SVKNII DVNC AN USSR. 28-42 [In Russian].

Glushkova, O. Yu., 1986. Late Pleistocene Glaciations of the North-East of the USSR, Authoref. Dis. ... Candidata Geograph. Nauk. Novosibirsk [In Russian].

Glushkova, O. Yu., 1996. Climatic Rhythms Reflection in the West Beringian Relief Morphology, Quaternary Climates and Vegetation in Beringia. Magadan, NEISRI FEB RAS. 94-114 [In Russian].

Glushkova, O. Yu., 2001. Geomorphological Correlation of Late Pleistocene Glacial Complexes of Western and Eastern Beringia, Quaternary Science Reviews. 20, 405-417.

Glushkova, O. Yu. 2011. Late Pleistocene Glaciation in North-East Asia, Quaternary Glaciations - Extent and Chronology: A Closer Look. Developments in North-East Asia. Ed. J. Ehlers, P. L. Gibbard and P. D. Hughes. Amsterdam, the Netherlands. 15, 865-875.

Glushkova, O. Yu., 2006. Late Pleistocene Glaciations of Beringia, Geology, Geography and Biologic Diversity of Northeastern Russia: Proceedings of the Far East Regional Conference Dedicated to the Memory of A. P. Vaskovsky and his $95^{\text {th }}$ Birth Anniversary (Magadan, November 28-30, 2006). Magadan, NESC FEB RAS. 108-113.

Glushkova, O. Yu., 2015. End-Moraine Complexes in Western Beringia, Conference Dedicated to the Memory of Academician K. V. Simakov, Conference Proceedings (Magadan, November 24-25, 2015). Magadan. 31-33 [In Russian].

Glushkova, O. Yu., Gualtieri, L., 1998. Features of the Late Pleistocene Glaciation of the Northern Part of the Koryak Upland, Changes in the Natural Environment of Beringia in the Quaternary Period. Magadan, NEISRI FEB RAS. 112-132.

Glushkova, O. Yu., Prokhorova, T. P., 1987. Formation Features of Late Pleistocene Glaciations and Sedimentation in the Elgenya River Basin (Upper Kolyma Highlands), Quaternary Period in the North-East of Asia. Magadan, SVKNII DVNC AN USSR. 68-89 [In Russian].
Glushkova, O. Yu., Prokhorova, T. P., 1989. Pleistocene Glaciations of the North-East of the USSR, Paleoclimates and Glaciation in the Pleistocene. Moscow, Nauka. 224-231 [In Russian].

Glushkova, O. Yu., Prokhorova, T. P., Degtyarenko, $Y u$. P., 1987. Pleistocene Glaciations and Related Features of Sedimentation and Restructuring of the Hydronetwork in the Koryak Upland, Quaternary Period in Northeast Asia. Magadan, SVKNII DVNC AN USSR. 33-54 [In Russian].

Glushkova, O. Yu., Smirnov, V. N., 2020. Neopleistocene Glacial Complexes in the North-East of Russia, Forum "Science of the North-East of Russia : Basic and Applied Research in the North Pacific and the Arctic", Magadan, March 5-6, 2020. Magadan, NEISRI FEB RAS. 23-26 [In Russian].

Gualtieri, L., Brigham-Grette, J., Glushkova, O., 2003. The Exent, Style and Chronology of Glaciation in Northeast Russia, XYI INQUA Congress Abstract No 55200, Session Quaternary Environments of the Eurasian North. Programs with Abstracts. 196.

Degtyarenko, Yu. P., 1984. Scale of Modern and Quaternary Glaciations in the Koryak Upland and Eastern Chukotka, Pleistocene Glaciations in the East of Asia. Magadan, SVKNII DVNC AN USSR. 66-76 [In Russian].

Ivanov, V. F., 1986. Quaternary Sediments of the East Chukotka Coast. Vladivostok, DVNC AN USSR [In Russian].

Klyukin, N. K., 1970. Climatic Regionalization, North of the Far East. Moscow, Nauka. 111-119 [In Russian].

Kolosov, D. M., 1947. Problems of Ancient Glaciation in the North-East of the USSR, Trudy GSU. Leningrad. Iss. 30 [In Russian].

Late Quaternary Vegetation and Climates of Siberia and the Russian Far East (Palynological and Radiocarbon Database), ed. P. M. Anderson, A. V. Lozhkin. Magadan, NESC FEB RAS, 2002 [In Russian].

Laukhin, S. A., Jiang Chiming, Pushkar, V. S., Cherepanova, $M$. V., 2006. Last Glaciation in the North of East Chukotka and the Paleooceanography of the North Pacific, Doklady Akademiyi Nauk. 411 (3), 405-409 [In Russian].

Lozhkin, A. V., Anderson, P. M., Belaya, B. V., Glushkova, O. Yu., Kozhevnikova, M. V., Kotova, L. N., 1996. Palynological Characteristics and Radiocarbon Dating of Lake Elgennya Sediments, Upper Kolyma, Quaternary Climates and Vegetation in Beringia. Magadan, SVKNII FEB RAS. 50-64 [In Russian].

Lozhkin, A. V., Anderson, P. M., Brown, T. A., Vazhenina, L. N., Glushkova, O. Yu., Kotov, A. N., Matrosova, T. V., 2005. Glaciation of the Anadyr Lowland (by Lake Sediments), Pages of the Quaternary History of NorthEast Asia. Magadan, NEISRI FEB RAS. 4-22 [In Russian].

Novaczyk, N. R., Minyuk, P., Melles, M., BrighamGrette, J., Glushkova, O. Yu., Nolan, M., Lozhkin, A. V., Stetsenko, T. V., Anderson, P. M., Forman, S. L., 2002. Magnetostratigraphic Results from Impact Crater Lake El'gygytgyn, Northeastern Siberia: a 300 Kyr Long HighResolution Terrestrial Paleoclimatic Record from the Arctic, Geophysical Journal International. 150 (1), 109-128. 
Petrov, O. M., 1966. Stratigraphy and Fauna of Marine Mollusks of the Quaternary Deposits in the Chukotka Peninsula. Moscow, Nauka [In Russian].

Recent Deposits and Paleogeography of the Pleistocene in Chukotka, 1980. Moscow, Nauka [In Russian].

Saks, V. N., 1953. Quaternary in the Soviet Arctic. Leningrad, Ministry of Marine and River Fleet [In Russian].

Sheinkman, V. S., 1987. Glaciology and Paleoglaciology of the Chersky Mountain System and Adjacent Areas in the North-East of the USSR. Moscow [In Russian].

Shilo, N. A., 1961. Quaternary Deposits of the YanaKolyma Gold-Bearing Belt, Conditions and Stages of Their Formation, Materials on Geology and Mineral Resources of the North-East of the USSR. Magadan. Iss. 66 [In Russian].

Shilo, N. A., Lozhkin, A. V., Anderson, P. M., Belaya, B. V., Stetsenko, T. V., Glushkova, O. Yu., Brigham-Grette, J., Melles, M., Minyuk, P. S., Novachek, N., Forman, S., 2001. The First Continuous Pollen Chronicle of Climate and Vegetation Changes in Beringia over the Past 300K Years, Doklady Akademiyi Nauk. 376 (2), 231-234 [In Russian].

Smirnov, V. N., Glushkova, O. Yu., 2012. Glacial Complexes on the Taigonos Peninsula, Geomorphology and Paleogeography of Polar Regions, Proceedings of the Joint International Conference, Symposium "Leopoldina" and Meetings of the INQUA Peribaltic Working Group, St. Petersburg, St. Petersburg State University, September 9-17, 1912. Ed. I. A. Zhirov, V. Yu. Kuznetsov, D. A. Subetto, J. Tide. St. Petersburg. 226-229 [In Russian].

Smirnov, V. N., Glushkova, O. Yu., 2018. Middle Pleistocene Tectonic Activation in the Verkhoyansk-Chukotka Area of Mountain Building, Problems of Tectonics and
Geodynamics of the Earth's Crust and Mantle Materials of the L Tectonic Meeting. Moscow, GEOS. 2, 199-202 [In Russian].

Spektor, V. B., Spektor, V. V., 2008. Regime of the Revived Mountain Building of the Verkhoyansk-Kolyma Mountain Area, General and Regional Problems of Tectonics and Geodynamics, Materials of the XLI Tectonic Meeting. Moscow, GEOS. 2, 291-294 [In Russian].

Stauch, G., Gualtieri, L., 2008. Late Quaternary Glaciations in Northeastern Russia, Journal of Quaternary Science. 23 (6-7), 545-558.

Stauch, G., Lehmkuhl, F., Frechen, M., 2007. Luminescence Chronology from the Verkhoyansk Mountains (North-Eastern Siberia), Quaternary Geochronology. 2, 255-259.

Vaskovskiy, A. P., 1959. Brief Outline of Vegetation, Climate, and Chronology of the Quaternary in the Upper Reaches of the Kolyma and Indigirka Rivers, and on the Sea of Okhotsk Northern Coast, Ice Age on the Territory of the European Part of the USSR and Siberia. Moscow, Lomonosov Moscow State University. 510-556 [In Russian].

Verkhovskaya, N. B., 1986. Pleistocene in Chukotka. Vladivostok, DVNC AN USSR [In Russian].

Vesnin, V. V., Viira, V. I., Kartashov, I. P., 1962. History of Glacial Relief Formation around Lake Jack London, Doklady Akademiyi Nauk USSR. 147 (3), 2101-2104 [In Russian].

Voskresensky, S. S., Chanysheva, M. N., Voskresensky, I. S., Karevskaya, I. A., Polosukhina, Z. M., 1984. Pleistocene Glaciations in the Kolyma Basin, Pleistocene Glaciations in the East of Asia. Magadan, SVKNII DVNC AN USSR. 57-65 [In Russian].

Yanina, T. A., 2014. On the New Stratigraphic Scale of the Quaternary System, MSU Vestnik. Series 5. Geography. 85-87 [In Russian]. 